\title{
A small speech community with many small languages: the role of receptive multilingualism in supporting linguistic diversity at Warruwi Community (Australia)
}

Ruth Singer

Australian National University

Canberra ACT 0200

ruth.singer@gmail.com

\begin{abstract}
At Warruwi Community (pop. 400), nine very different Indigenous languages are still widely used, which is unusual in the contemporary Australian Indigenous context. Using the receptive multilingual mode, speakers frequently address one another in different languages. This mode offers speakers of small languages such as Mawng (ca. 400 speakers) an alternative to accommodating to larger languages such as Yolngu-matha (ca. 2000 speakers). Although not unique to Warruwi, receptive multilingual practices are part of a set of "mutually constituting ideologies and practices" (Nakassis 2016) that co-construct a speech community where many small languages flourish.
\end{abstract}

Keywords

Indigenous Australia ; speech communities ; receptive multilingualism ; identity ; language ideologies ; language maintenance

\section{Introduction}

Warruwi Community in northern Australia is unusual because many Indigenous languages are still being learned by children. Elsewhere in Australia linguistic diversity has declined sharply. Yet, at Warruwi at least nine languages are spoken amongst 400 people (Singer and Harris, 2016). How are so many languages still being maintained in this community? Experience in other contexts suggests that multilingual language practices and ideologies are likely to play an important role in supporting this intensive linguistic diversity (Kroskrity, 1993; Sicoli, 2011). Warruwi is one of the last places in Australia where so many Indigenous languages co-exist which makes it a good place to look at the practices and ideologies that support such an abundance of small languages. Given the paucity of work on language survival, it is worth asking what enables so many languages to be passed on across the generations in a context where there is dramatic social change, the loss of many local languages and the introduction of a lingua franca (English).

Michael Silverstein has long theorised about "local language communities that have survived at the peripheries of imperial and currently globalizing projects" (Silverstein, 2015). He points out that scholars need to investigate "the nature of such plurilingual social formations - speech communities with complex communicative economies". Warruwi is clearly a 'complex communicative economy' in the way it integrates a multiplicity of languages and social groupings. In this article, we will look at how the practice of receptive multilingualism at Warruwi is integral to multilingualism at Warruwi. Receptive multilingual practices involve people speaking to one another in different languages. These practices are contextualised in this article within language ideologies and broader discourses about social and cultural diversity that circulate at Warruwi. Receptive multilingualism emerges as a way 
for people to maintain quite different repertoires and patterns of language use even in the one family.

Warruwi is a place where many small languages are still spoken. There are no Indigenous Australian languages with more than a few thousand speakers so all would be categorised as 'small' from an international perspective. The north coast of Arnhem Land is home to many languages with only a few hundred speakers, and the high levels of linguistic diversity in this area result from the fact that these small languages differ dramatically from one another in vocabulary and grammar. So a small language is defined here as one with 500 or fewer speakers and the term 'small' is not intended to imply 'minority language' or a lack of importance (cf. Pietikäinen et al., 2016). As Carr and Lempert (2016) argue, 'scale matters'. The fact that these languages are so small demands a more fine-grained study of the role they play in interactions, in families and in people's lives.

Receptive multilingualism is a practice that is particularly prevalent at Warruwi and seems to help make Warruwi a place where many small languages can flourish. The way people orient to receptive multilingual practices as 'ordinary' and not worthy of comment makes receptive multilingualism a candidate for being one of the 'shared norms' that defines the speech community. To introduce the practice, two examples are shown below. Extract (1) is from a recording of a naturalistic conversation between Nancy Ngalmindjalmag ${ }^{1}$ and Richard Dhangalangal. Nancy uses Mawng (italics) and Richard uses his Dhuwal variety of Yolngu-matha (underlined).

(1)

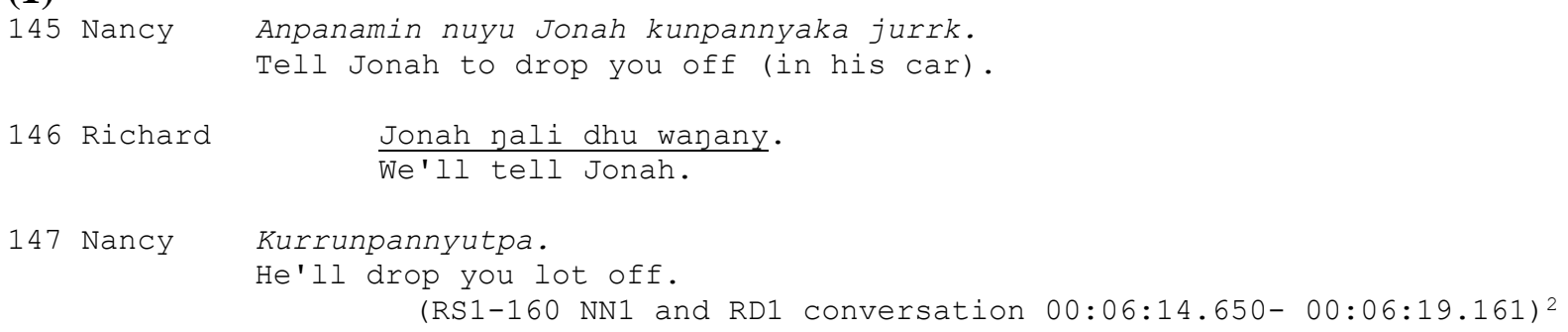

Nancy was born at Warruwi and has spent all her life there, although she travels frequently around Arnhem Land, to visit family and participate in Uniting Church activities which also regularly take her to the regional capital Darwin and interstate. Her husband Richard moved to Warruwi from eastern Arnhem Land in 1980 when they were married. Having spent time with Nancy and Richard outside of a research context, I noticed that they spoke to each other in this way most of the time, with Nancy addressing Richard in Mawng and Richard replying in Yolngu-matha. Even though Nancy can speak Yolngu-matha fluently, she only occasionally addresses Richard in Yolngu-matha. Extract (2) is from an interview in which Nancy speaks Mawng to Janet Mardbinda, who replies in Bininj Kunwok (underlined).

(2)

055 Janet Saturdayni bu ngarridurndi.

\footnotetext{
${ }^{1}$ All names of participants are real names (as requested by them). Italics is used for the Mawng language throughout and underlining is used for Kunwinjku and Yolngu-matha (only one of these languages are used in each extract).

2 These recordings are archived in the PARADISEC digital archive
} 
Saturday is when we came back.

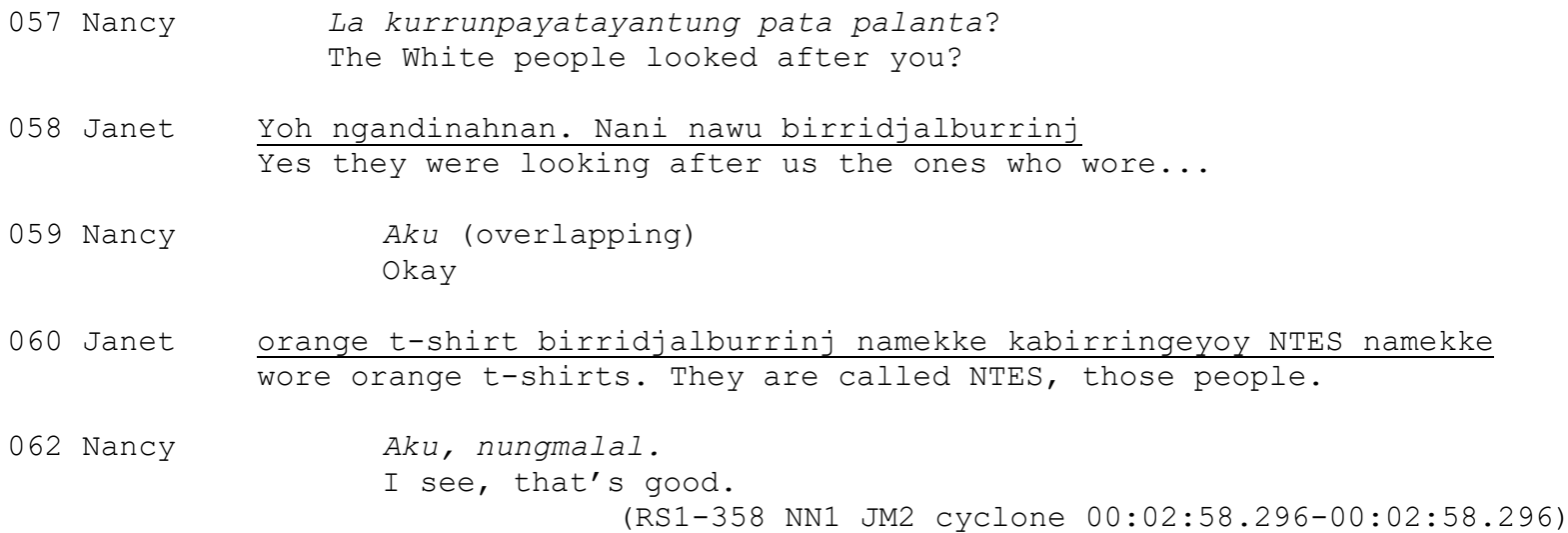

As these examples show, when people talk to one another at Warruwi, they may each speak a different language. This receptive multilingual mode of interaction is the antithesis of two better known phenomena; accommodation and code-switching. Receptive multilingual practices go against the supposed universal tendency for speakers to accommodate, for multilingual speakers to find those shared parts of their linguistic repertoire as needed (Giles and Powesland, 1975; Giles and Ogay, 2007). In both the recordings cited above, Nancy could have matched her language to that of her interlocutor, as she is a fluent speaker of Yolngu-matha and Bininj Kunwok as well as Mawng. The receptive multilingual mode also involves minimisation of code-switching as each speaker sticks mainly to one language.

At Warruwi, people often use different languages when they are talking to each other even if they have overlapping repertoires. This highlights the socio-political motivations for receptive multilingual practices which are also being recognised in recent work on receptive multilingualism in European contexts (Bilaniuk, 2005; Verschik, 2012). Receptive multilingual practices at Warruwi fit with the local ideal of being 'different together' (Brown, 2016). The social and linguistic diversity at Warruwi is seen as essential to social harmony rather than as a barrier, underscoring the need for people to assert diverse identities instead of everyone identifying as the same (cf. Sutton, 1997). Because only speaking a language is seen as socio-politically relevant, receptive multilingualism allows people greater scope to index aspects of their identity through language choice without the concomitant pressure of forcing others to speak that language, with its particular socio-political associations.

The diverse repertoires and modes of language use at Warruwi raise questions about how to define the multilingual speech community. Although Bloomfield's (1933) initial proposal of the speech community required members of the speech community to speak the same language, Gumperz (1968) proposed instead that members of a speech community have a "shared set of social norms"(p.382). This conceptualisation, without reference to a shared language, opened up the possibility of theorising multilingual speech communities. Shared norms are reflected in how people evaluate one another's language use by drawing on 'shared interpretations of indexicality' (Silverstein, 2015). These shared norms include an understanding of language ideologies that circulate in the community and the acceptance of certain widespread language practices such as receptive multilingualism. Defining the speech community as the location of shared social norms voids any requirement for its members to have similar or even partially overlapping linguistic repertoires. Yet most 
studies of multilingualism focus on people with quite similar repertoires, such as a minority ethnic groups with a single language identity.

At Warruwi, people's repertoires often do not seem to overlap at all until we look at people's hidden receptive competences. The speech community is a contested model (Rampton 2010) yet researchers often find clusters of 'mutually constituting ideologies and practices' (Nakassis 2016). At Warruwi, a particular constellation of histories, social groups and patterns of mobility has normalised specific multilingual practices so that they pattern quite differently to neighbouring communities (see Vaughan, this issue). This paper concludes by comparing understandings of Warruwi as a speech community with earlier work on speech communities in Indigenous Australia, arguing for the validity of the speech community as a unit of analysis in this context. The focus of the paper is the practice of receptive multilingualism, explored through a study of three closely connected people with very different language identities and linguistic repertoires. The data drawn on include conversations between the three people, and interviews with each of them with them that include the visual mode through a drawing task.

\section{Languages at Warruwi}

Warruwi Community is a settlement of around 400 people on a very small island off the remote north coast of Australia, an hour's flight from the regional capital, Darwin. Warruwi Community was established initially as a Methodist mission, 100 years ago. It is situated within Arnhem Land, a large area of Indigenous-owned land and is referred to as a 'Remote Indigenous Community' (Figure 1).

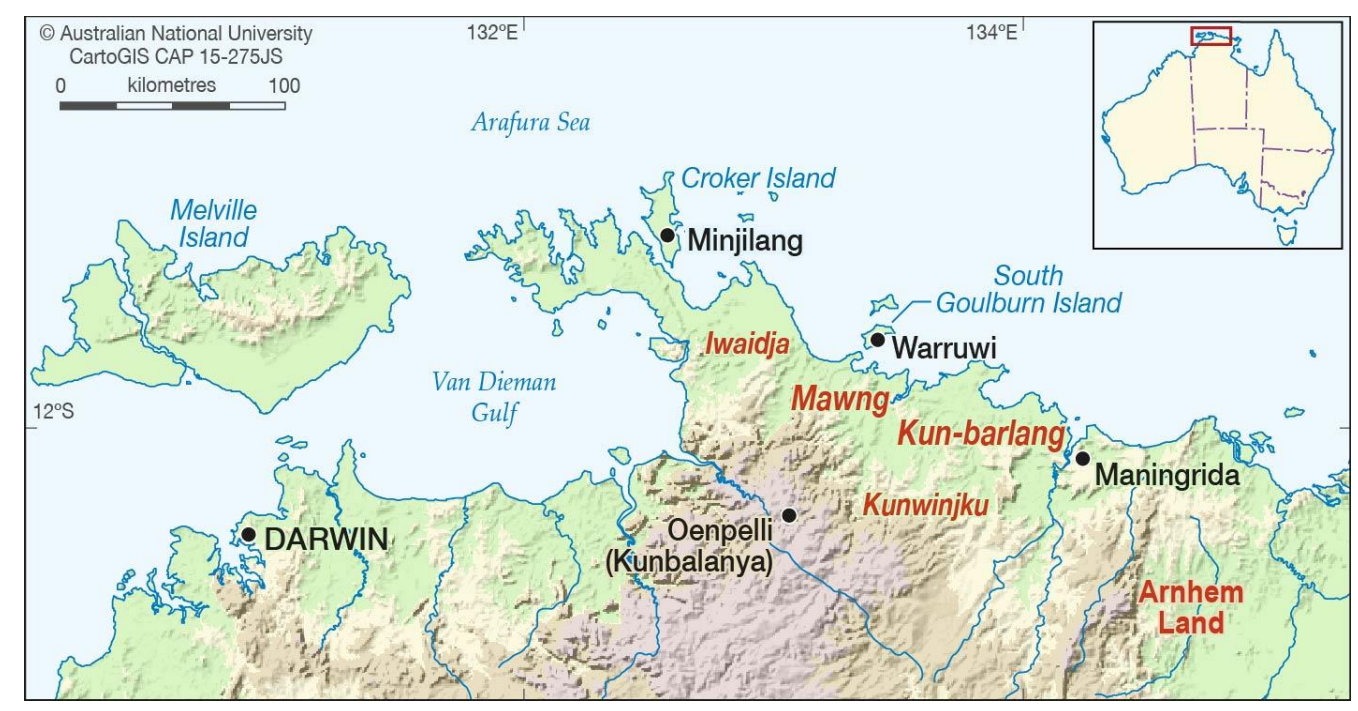

Figure 1 Location of Warruwi Community, nearby remote communities and the regional capital Darwin

At Warruwi Community many Indigenous languages are still being spoken and learned by children. This contrasts with the situation in most Indigenous communities in northern Australia where multilingualism has declined so that a single Indigenous language is being passed on to younger generations. For example, Wadeye Community in the Daly River area has 2000 people but children grow up using only Murrinhpatha, even though 20 different languages are associated with this area and a few are still used by older people. Maningrida community (see Figure 1 ) is one of few other places in Australia where the same kind of 
intensive linguistic diversity persists as at Warruwi (Elwell, 1982; Green, 2003a; Vaughan, forthcoming; Vaughan, this issue).

The range of languages spoken at Warruwi is depicted in Figure 2 below. The diagram aims to convey a sense of the number of speakers of each language at Warruwi as a proportion of the total number of speakers of that language. The larger circles indicate the total number of speakers of the language. The smaller circles within the larger circles indicate the proportion of speakers of that language who live at Warruwi (estimates from Singer and Harris, 2016). So, for example we can see that most Mawng speakers live at Warruwi, whereas most speakers of Yolngu-matha varieties live elsewhere.

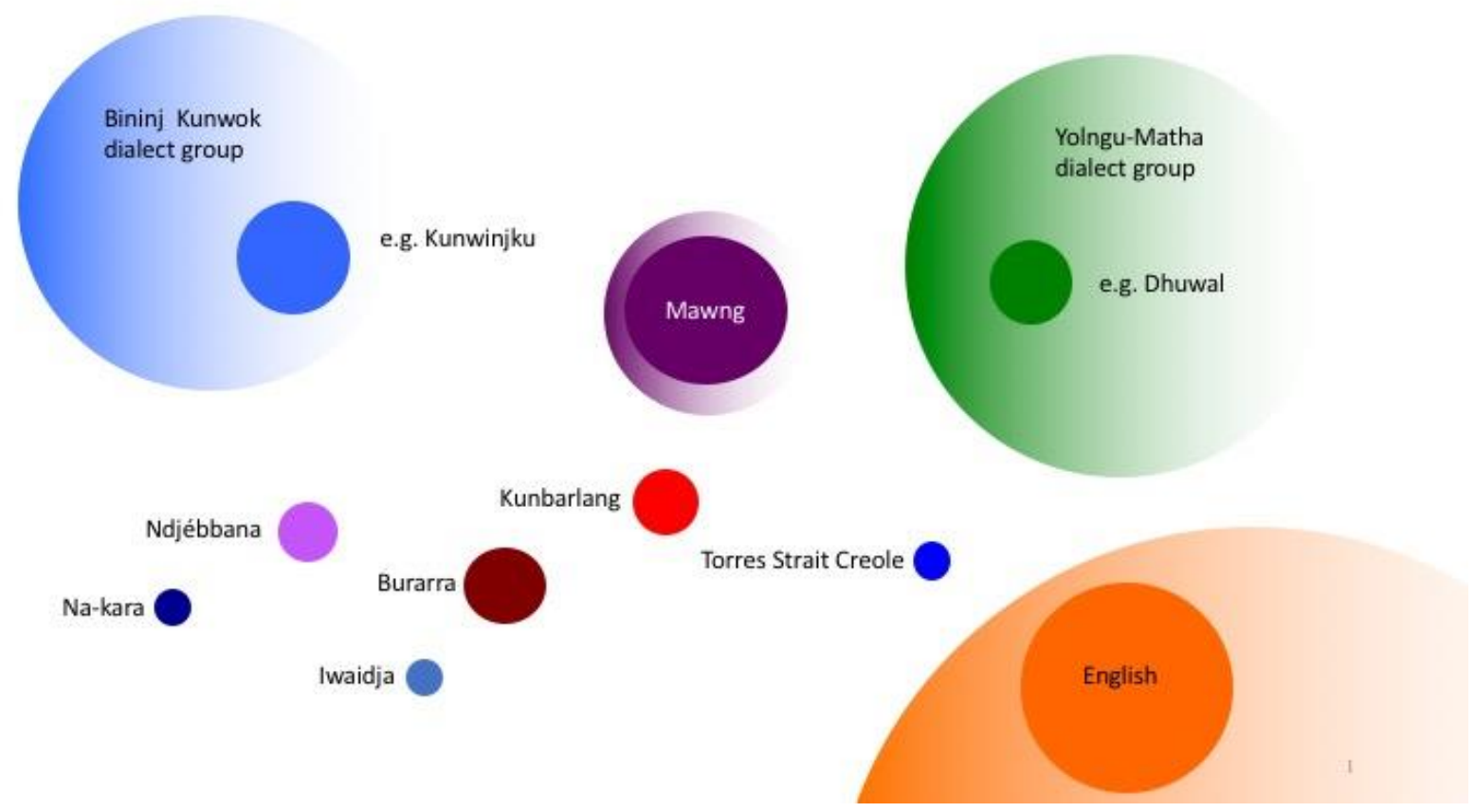

Figure 2 Languages used at Warruwi as proportion of total speakers

The Mawng language is often described as the language that belongs to Warruwi because it is now associated with the land that Warruwi Community is on. In interviews, people sometimes describe it as 'the common language' of Warruwi although it is only spoken by at most two thirds of people at Warruwi. People who have lived at Warruwi for some time usually understand Mawng, however, even if they do not speak it. Mawng has around 400 speakers $^{3}$, most of whom live on Warruwi, or did at some point in their lives. The two most widely spoken Indigenous languages at Warruwi after Mawng are Bininj Kunwok and Yolngumatha. These names are used by linguists to refer to the two largest dialect assemblages in Arnhem Land and their speakers number in the thousands.

The Kunwinjku dialect of Bininj Kunwok is the one that is most widely known at Warruwi, although there are also speakers of Kuninjku. The Kunwinjku dialect is associated with land that is directly inland from the coastal area associated with Mawng (see Figure 1). The total number of Bininj Kunwok speakers across Arnhem Land is estimated at around 1200, with a further 800 people thought to be able to understand the language. Dhuwal varieties of the

\footnotetext{
${ }^{3}$ My estimate. This includes second language speakers of Mawng. For sources on all other estimates see Singer and Harris (2016).
} 
Yolngu-matha dialect are widely used at Warruwi, and the Galpu and Gupapuyngu varieties are also heard. Dhuwal varieties include Djambarrpuyngu, a variety associated with the communities of Milingimbi and Elcho Island. The area of land with which Yolngu-matha is associated is the north-east corner of Arnhem Land to the east of the remote community of Maningrida, which is shown on Figure 1. There are estimated to be more than 2000 Yolngumatha speakers. In general, speakers of the larger languages such as Bininj Kunwok and Yolngu-matha tend to be less multilingual than those who speak smaller languages with fewer than 500 speakers (Elwell, 1977). So even though all Australian languages have a small number of speakers from a global perspective (Lupyan and Dale, 2010) there is a clear difference between the smaller and larger languages in the local western Arnhem Land language ecology.

The remaining languages in Figure 2 are used by smaller groups of people at Warruwi and are represented by a single circle only for reasons of space. Burarra is estimated to have around 2000 speakers altogether and is the most widely used language at Maningrida community (Vaughan, this issue; Margaret Carew, pers. comm.). Ndjébbana and Na-kara are also spoken in Maningrida and surrounds but they are much smaller languages than Burarra. Quite a few people at Warruwi can speak or at least understand Ndjébbana which is estimated to have 250 speakers altogether but fewer know Na-kara. Kunbarlang and Iwaidja are languages which were spoken by people who own land directly to the east and west of Mawng country, along the coast. These languages were spoken by people who owned land on the coast like Mawng speakers (see Figure 1) whereas the Bininj Kunwok varieties such as Kunwinjku are associated with the so-called stone country which is inland. Iwaidja and Kunbarlang are known now only by a handful of old people and they still have a strong symbolic significance, although their descendants mainly speak Mawng or Kunwinjku. A few Torres Strait islander families also live at Warruwi and they speak Torres Strait Creole ${ }^{4}$.

The languages spoken at Warruwi belong to six different genetic groupings as shown by the boxes in Figure 3.

\footnotetext{
${ }^{4}$ Torres Strait Creole is the most widely used language of Torres Strait Islanders. The Torres Strait lies between the northern tip of the state of Queensland in Australia and Papua New Guinea.
} 


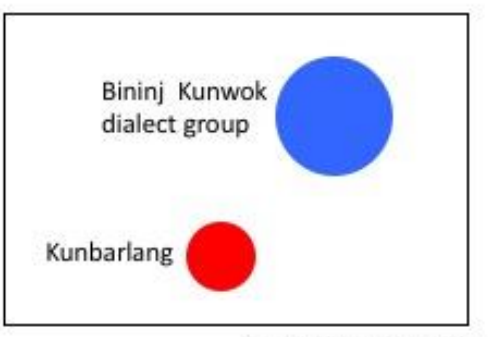

Gunwinyguan family

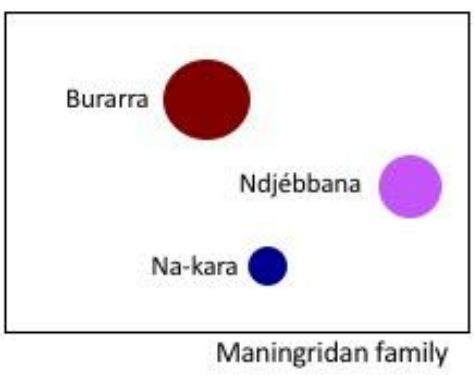

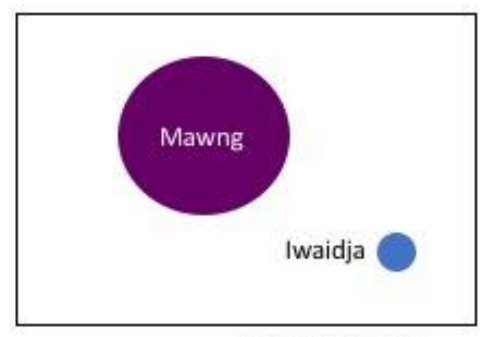

Iwaidjan family

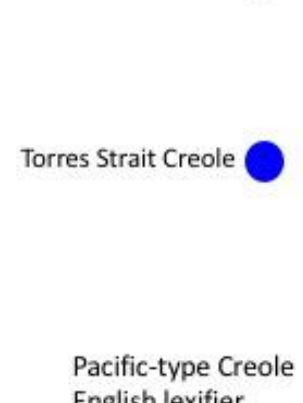

English lexifier
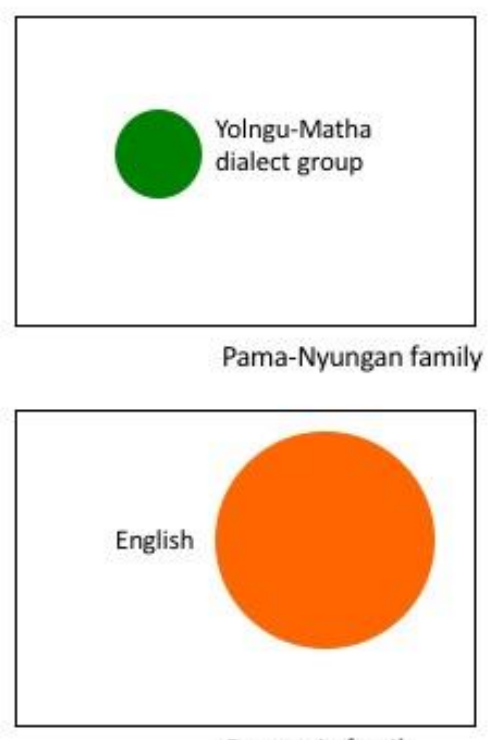

Germanic family

\section{Figure 3 Language families of Warruwi languages}

The Indigenous languages spoken at Warruwi fall into four language families. The Iwaidjan language family includes Mawng as well as its sister language Iwaidja. The other languages in this language family are no longer spoken and they include Manangardi, Amurdak, Marrku, Garig and Ilgar. The Gunwinguan family includes a number of languages that are still spoken. These are associated with groups referred to locally as 'Freshwater people' because they are found to the inland with the exception of Kunbarlang which is associated with the stretch of coast to the east of Mawng country (see Figure 1). The Maningridan language family has been relatively recently proposed (Green, 2003b) and includes four languages that are associated with land near Maningrida.

The Yolngu-matha dialect group is part of the Pama-Nyungan family, the largest family of Australian languages, which stretches right across the continent. Like most other PamaNyungan languages, Yolngu-matha languages are predominantly suffixing in their morphology, whereas the other Indigenous languages spoken at Warruwi mark grammatical relations with verbal pronominal prefixes (Capell, 1942). Torres Strait Creole is an Englishlexifier creole (Shnukal, 1991). English as spoken at Warruwi shows a lot of variation but shares features with other varieties of so-called 'Aboriginal English' spoken in the region. Most people at Warruwi speak English as a second language but some have spoken English since birth. This article focusses on the dynamics of Indigenous heritage languages spoken at Warruwi so does not look at the dynamics between Indigenous languages and English which are quite different (cf. Vaughan, forthcoming). This paper will look at how the three most widely spoken languages are used in conversation: Mawng, Bininj Kunwok and Yolngumatha.

Figure 3 shows that these three languages are in separate language families. Although the languages have similar phoneme inventories, there is little mutual intelligibility between them, because of the lack of shared vocabulary. Mawng and Kunwinjku have long been in contact so they have a small percentage of shared vocabulary. In addition, they are both 
'prefixing languages' so they both mark grammatical function, person and number via prefixes on verbs. Mawng and Yolngu-matha have very little shared vocabulary, apart from English borrowings, and some words from Macassarese, the language of Indonesian fisherman who used to visit the north coast of Australia (Clark and May, 2013). The languages spoken at Warruwi reflect the diverse repertoires and identities that people have, which are explored in the next section.

\section{Local perspectives on diversity at Warruwi}

Figure 3 above presents the diversity of languages at Warruwi within the major classification scheme used in linguistics that groups languages according to evidence that the languages developed from a common ancestor. At Warruwi, linguistic diversity is just one of a range of kinds of social, cultural and political diversity that people draw on to differentiate themselves from one another (cf. Sutton, 1978). In a special issue of this journal, The social life of diversity talk, Faudree and Schulthies (2015) point out that our conception of 'diversity' was born with the growth of modern nations as "diversity within national boundaries and mobility across them were viewed as challenges to state projects aiming to forge a collective national identity and a national consensus of practice". In her contribution, Faudree (2015) suggests that studying local perspectives on diversity "might help us sidestep the trap that both Silverstein (2015) and Moore (2015) identify, following Scott's Seeing Like a State (1999): namely, that of seeing diversity the way the state sees it." This section draws together some local perspectives on diversity at Warruwi.

Faudree (2015) looks at discussions in comments on YouTube videos of an annual Sierra Mazatecan musical competition. She finds these "local debates around same-ness and difference" provide a window into perspectives on diversity among Mazatecans. Discussions of traditional music and dance at Warruwi can also bring local discussions of diversity to the fore (Brown, 2016; O'Keeffe, 2016). Explaining why traditional ceremonies must involve a number of distinctly different social groups, Inyjalarrku song custodian David Manmurulu discusses the importance of creating a context in which people can be 'different together' (Brown, 2016). Preparations for ceremonies involve elders deciding on the set of social groups which will play key roles. This is true not only of long-practiced ceremonies such as funerals but also of newer ceremonies such as the celebration of the centenary of the mission in June 2016 (Singer, 2018). People are not expected to represent the same group in every ceremony, they can draw on their multiple connections and claims of authenticity to represent different groups across different events.

This flexibility is highlighted in a story told to me by White musicologist Reuben Brown. Dancing at Warruwi for a recording for a PBS documentary, Brown painted his body in the bedjekbedjek style where white ochre mixed with water is slapped across the body. This design is associated with the Mok clan, a freshwater group who adopted Brown and first taught him about local song and dance traditions. In 2016, Reuben Brown travelled with David Manmurulu to perform a Mamurrng ceremony in the Daly River area, outside of Arnhem Land. While they were preparing for the performance, David told Reuben to paint himself with the white and yellow stripes of the Inyjalarrku design belonging to David's songset. My interpretation of this is that on this second occasion, David's intention was for Reuben to represent David's group instead of the Mok clan. Reuben's experience illustrates the contextual nature of identity at Warruwi. Indigenous people at Warruwi can lay claim to a range of social and linguistic groups through each of their four grandparents, other family, ties forged through the informal fostering of children, residence history and marriage. In 
Reuben's case he has multiple mentors in music and dance and each could claim him, or he could claim their group, depending on the context.

The complex yet flexible nature of identity at Warruwi has been illustrated with reference to ceremonies but is also relevant to language use. While many scholars of language and society recognise that identities are inherently multiple and many-faceted, the notion of 'one language - one people' is still ingrained in linguists' research practices. The notion of 'a language' is often assumed to have a one-to-relationship with a unique ethnic group. At Warruwi Community the notion of ethnicity best connects with the conceptualisation of Indigeneity more broadly, it does not have much meaning in terms of the other ways Indigenous people identify themselves one another at Warruwi. At a national level, the opposition between White and Indigenous is highly salient in Australia, and people at Warruwi embrace their identity as Indigenous/Aboriginal/Blackfella/arrarrkpi ${ }^{5}$. While not wanting at all to discount the significance of this pan-Indigenous identity at Warruwi, this paper focusses on diversity at a smaller scale, making connections between languages and identity by looking at how Indigenous people at Warruwi view themselves and one another, at a smaller scale than Indigeneity.

\section{Repertoires and identities: receptive competencies}

Receptive multilingual conversations like those which extracts (1) and (2) are taken from, do not exist in a vacuum. They exist together with specific language ideologies and particular kinds of linguistic repertoires. Describing their linguistic repertoires, most people list first the languages they 'speak' and then languages they only 'hear'. This bifurcated view people have of their language proficiencies is conventionalised and reflects the way that receptive multilingualism is not a practice we just happen to come across at Warruwi in conversations between certain people in certain contexts but is a phenomenon that connects with other practices and ideologies too, so exists at the scale of the speech community.

Before delving into accounts that people give of their linguistic repertoires, it is worth reminding ourselves that languages are not necessarily the most important aspects of people's identities at Warruwi (cf. Sutton, 1978:xi). The languages that people identify with are not straightforward reflections of other aspects of their identity or their ancestry, upbringing and life history. Languages are often invoked to support claims to particular land and clans. However, language use can also reveal shared histories between two groups that stress their distinctiveness. Language identities have become more significant in the delineation of social groups in western Arnhem Land in the past 100 years (Singer, 2018). The prominence of 'language-named tribes' as Rumsey (1989) calls them, has arisen in the recognition space (Pearson, 1997) under the influence of long-held European ideas about the primacy of language in circumscribing nationhood. Language identities take a range of forms at Warruwi and do not directly reflect the most significant social groups in western Arnhem land: patrilineal clans and clan aggregates. Language identities are often bound up with people's connections to particular families, friends, communities and places.

In this section, we will look how people understand their linguistic repertoires in relation to their broader identity. The language portrait is a tool used to get discussions of repertoires going in interviews'

\footnotetext{
${ }^{5}$ This word is often used to mean simply 'Indigenous (person)' but it has other meanings across a range of scales including 'man', 'person', 'Indigenous person associated with area where the word arrarrkpi is used'.
} 
The language portrait task, popularised by sociolinguist Brigitta Busch (Busch, 2006, 2010, 2012), has been taken up by researchers working in diverse contexts around the world because it provides a great starting point for people to discuss their languages (Bristowe et al., 2014; Coffey, 2015; Dressler, 2015; Pietikäinen and Pitkänen-Huhta, 2013). I used the language portrait task in conjunction with linguistic biography interviews. These are relatively informal biographical interviews that begin with the question "Tell me about the languages you have used in your life". Before this, participants are asked if they would like to create a language portrait. If so, they are given an outline of a body in black and asked to colour it in using a different colour for each language. After she made the picture above, I interviewed Nancy about her picture. She began by mentioning the four languages Mawng, Djambarrpuyngu (Dhuwal, Yolngu-matha), Kunwinjku and Kunbarlang and stating the colour she had used for each. She singles out Mawng and Kunbarlang in particular, in contrast to Djambarrpuyngu and Kunwinjku, in extract (3) below.

(3)

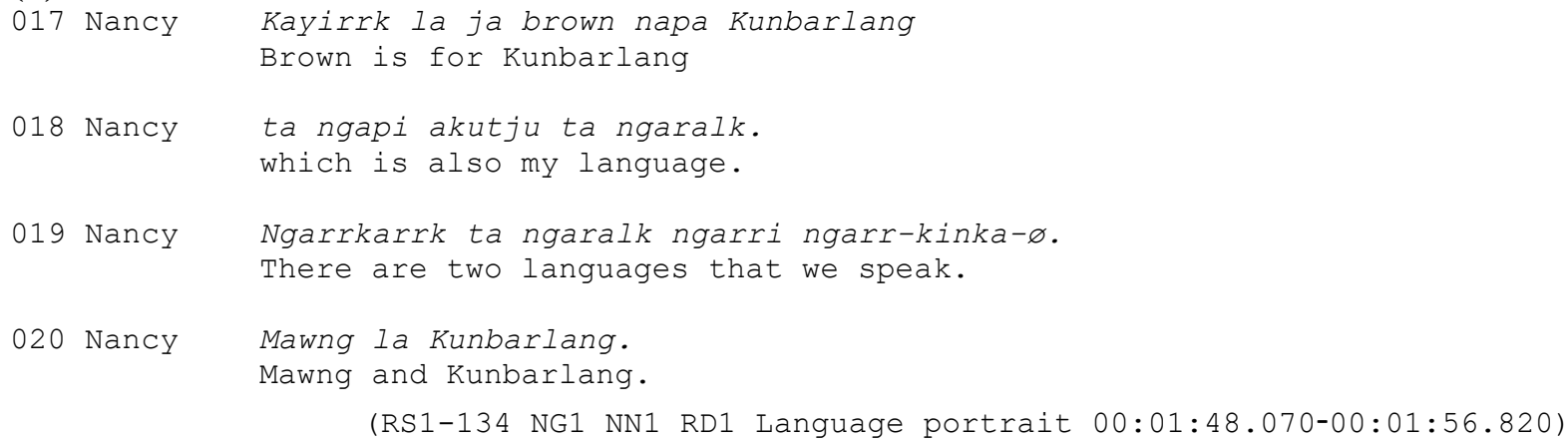

In extract (3) Nancy refers to Kunbarlang as ta ngapi akutju ta ngaralk 'also my language', referring back to her mention of Mawng earlier as her language. She used the personal pronoun ngapi ' 1 ' to refer to Mawng but did not use personal pronouns to refer to Kunwinjku or Djambarrpuyngu. In line 19 Nancy then uses the plural first person pronoun again (ngarri) to refer to both Mawng and Kunbarlang. Her use of the first person exclusive pronoun ngarri excludes the hearer and suggests a specific group of people which she is a part, that own these two languages. At this point in the discussion Nancy has mentioned four languages that she speaks-Mawng, Kunwinjku, Djambarrpuyngu and Kunbarlang-but has claimed ownership of only two.

Then Nancy turns to languages in which she is not as fluent, discussing the languages Iwaidja, Na-kara and Ndjébbana in extract (4) below.

(4)

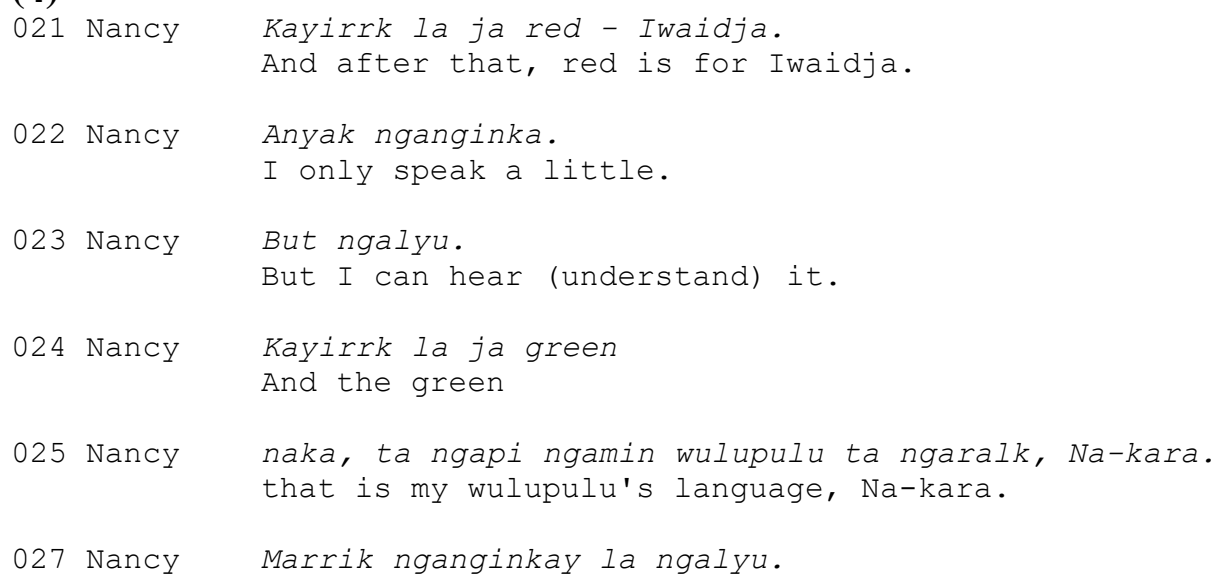


About Iwaidja, shown in red on the foot in her language portrait, Nancy says Anyak nganginka. 'I only speak it a little' (line 134) but she mentions that she can 'hear' it. The verb -alyu she uses here can mean 'hear', 'listen' or 'understand'. It tends to be translated to the English word hear in this context. People often talk in English about being able to 'speak' a language, or just 'hear', i.e. understand it in Arnhem Land and also historically at least, in Cape York (Rigsby, 2005). Nancy goes on in line 27 to say of the Na-kara language Marrik nganginkay la ngalyu 'I don't speak it but I can understand it'. Interestingly when she mentioned Djambarrpuyngu earlier in this recording Nancy explicitly mentioned that she could both speak and understand it, as shown in line 14 in extract (5) below.

(5)

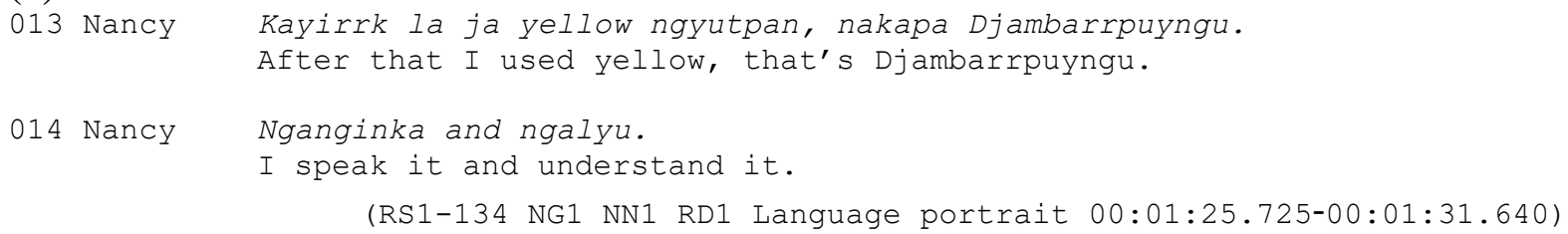

Nancy explicitly mentioned her ability to both 'speak' and 'hear' Djambarrpuyngu because this would not necessarily be assumed given her heritage as a western Arnhem lander. Many people learn to understand or 'hear' their spouse's language without ever learning to speak it, however, Nancy has also learned to speak her husband's language, even though it is very different to the languages she grew up with. The distinction that is made between 'speaking' a language and 'hearing' across a wide area of northern Australia reflects the widespread practice of receptive multilingualism (Singer and Harris, 2016). I refer to the ability to 'hear' but not 'speak' a language as 'receptive competence'.

When Nancy talked about the Maningridan language Na-kara in extract (4) she referred to her wulupulu, a type of relative three generations distant, which includes a person's mother's mother's mother. She also made a connection to Ndjébbana through her wulupulu. In a separate interview, a few days earlier, Nancy made further connections between her ancestry and her linguistic repertoire. She designated Mawng her father's language, Kunwinjku her mother's language and Djambarrpuyngu her husband Richard's language. Nancy talks about Mawng and Kunbarlang as her own languages, making a claim to language ownership. In addition to owning land, clans are said to own the language associated with their land. The strongest claim to land and language is through one's father's father (I refer to the 'father' rather than specifically the father's father throughout this paper for simplicity). Nancy claims Mawng and Kunbarlang for this reason, through her father. It is not clear to me exactly why she claims two languages through her father. It is not unknown for a clan to own two languages (Sutton, 1978: 59) but it is likely that Kunbarlang ownership is being shared more broadly, because of its current precarity. It not being learned by many young people and there is a sense at Warruwi that Kunbarlang is precious, a treasure which needs attention and nurturing.

Nancy's language portrait includes English and gives English a prominent place. The parts of the body where different languages appear in her language portrait, do not reflect traditional associations between kin and body parts. We might expect a spouse's language to appear on the hip, or a mother's language to appear on the chest area, as these parts of 
the body represent those kinds of kin at Warruwi (Green et al., in press). However, we find that the parts of the body where more important languages appear in language portraits by people at Warruwi matches what has been found in other parts of the world. The head and chest area is where people commonly put those languages that are most important to them (Busch, 2010). Nancy puts Mawng on both her head and chest which reflects her claim that it is her language. Although English appears on the stomach area in Nancy's language portrait, many others at Warruwi did not include English in their language portraits, most likely because they did not see it as one of 'their' languages. Nancy includes English in quite a central position which could reflect her perspective on her own life, spent working with non-Indigenous people: at the clinic at Warruwi and in her travels around Australia, representing Indigenous people at Uniting Church gatherings.

Ending the discussion of her language portrait, Nancy stresses the significance of the languages she has depicted.

(6)

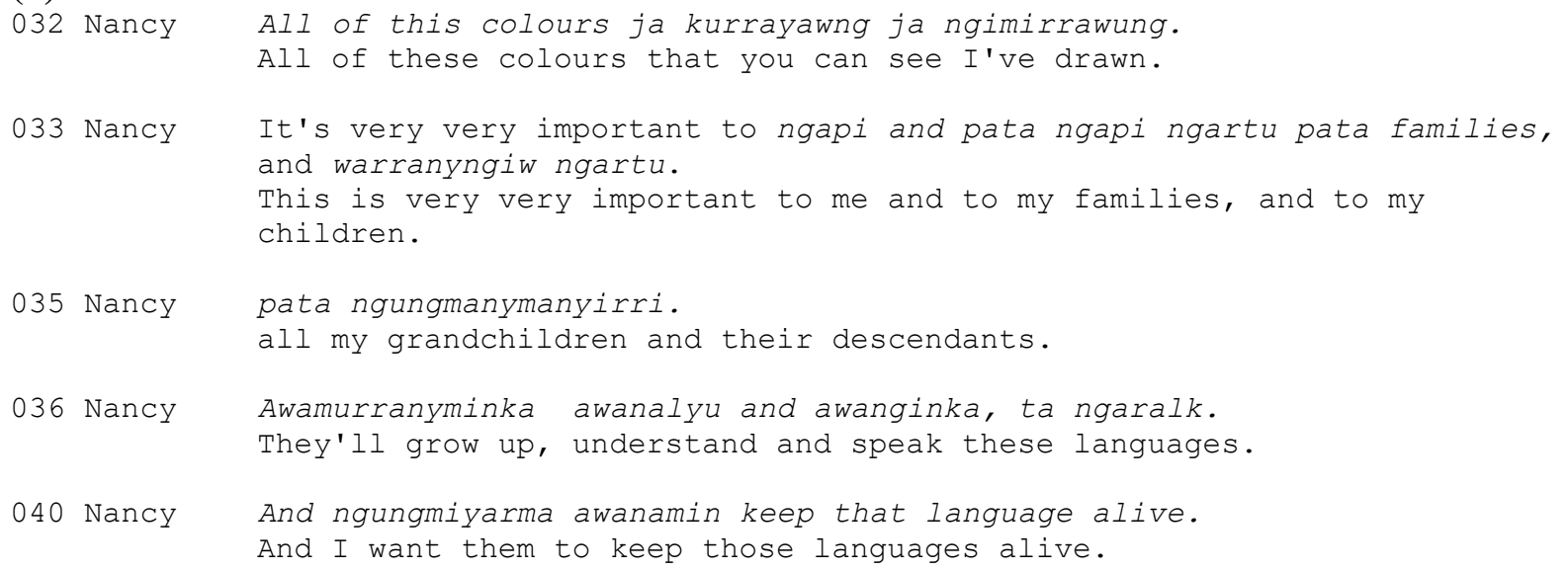

As Nancy points out, what may seem like a light-hearted colouring activity represents something of overwhelming importance to her, her ancestors and her descendants. We will now look briefly at language portraits by the other two speakers in extracts (1) and (2); Richard Dhangalangal and Janet Mardbinda. In extract (1) Nancy talks with her husband Richard who up in Milingimbi, in eastern Arnhem Land and moved to Warruwi when he married Nancy in 1980. Richard's language portrait is shown in Figure 4 below. 


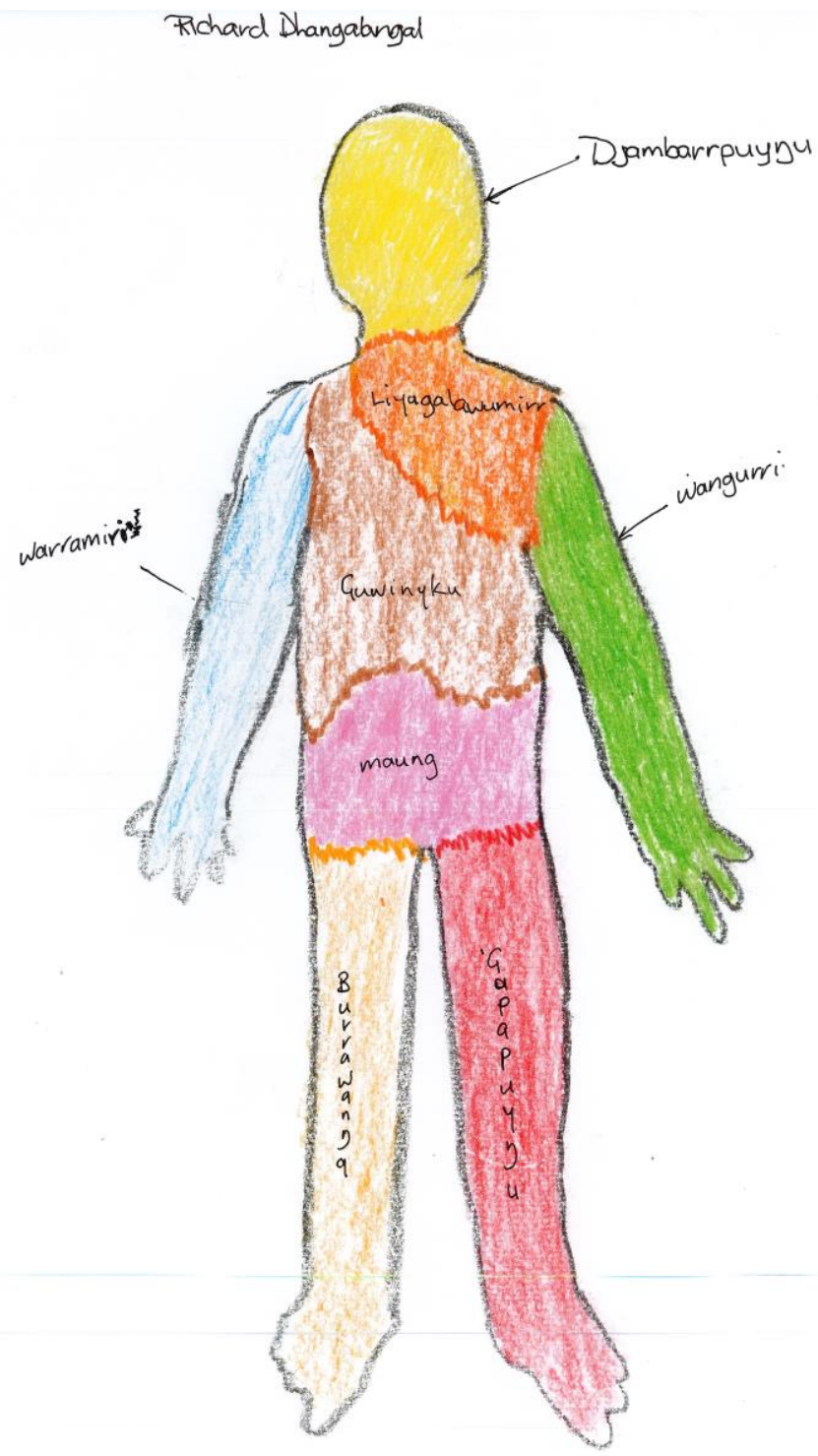

Figure 4 Richard's language portrait

Richard's language portrait shows six eastern Arnhem Land languages and two western Arnhem Land languages: Mawng and Kunwinjku. He does not include English on his portrait, although like Nancy he uses English in his work with the Church and his Christian studies. In a linguistic biography interview conducted by linguist Salome Harris, Richard talked about the two languages on his head and shoulders: Djambarrpuyngu and Liyagalawumirr. In eastern Arnhem Land, each clan is said to have its own language and this language takes the same name as the clan. So, the names on Richard's language portrait are also names of clans associated with eastern Arnhem Land. Richard talks about how he grew up with a man of the Liyagalawumirr clan as his father. As a result, he learned to speak Liyagalawumirr rather than his birth father's clan language Djambarrpuyngu ${ }^{6}$. Regardless, he identifies strongly with the Djambarrpuyngu clan language and coloured the head in yellow to

\footnotetext{
${ }^{6}$ The language name Djambarrpuyngu is often used to refer to a Yolngu-matha variety used widely in Milingimbi and Elcho island communities which some analyse as a koine. This is how Nancy uses the term Djambarrpuyngu. However in Richard's discussion of his language portrait he uses the name Djambarrpuyngu in a more restricted sense to refer to the clan language Djambarrpuyngu.
} 
represent this variety. He also colours his chest and one shoulder in orange to represent Liyagalawumirr.

The father's language is of primary importance to identity in both eastern and western Arnhem land. In an ideal world, everyone would learn to speak their father's language from birth but very often this does not happen, for example because the father and his family are not around during childhood or because of language shift across the generations. Nancy's strong statement of ownership of Mawng and Kunbarlang also reflects the centrality of the father's language, these two languages being associated with her father. The importance of the father's language is connected to the fact that land ownership passes through the male line, and language is associated with land. In this way, languages are also seen to be owned, and those who own a language, through their father and his father, have the most authority to speak about that language.

Although Nancy can speak Richard's Dhuwal variety of Yolngu-matha, Richard does not speak Mawng or Kunwinjku beyond a few words and phrases. He does understand Mawng very well, as demonstrated by the fluency of their conversation when Nancy speaks Mawng to him and he replies in his Dhuwal variety. Extract (7) comes from the same recording as extract (1). The turn-taking and joint construction of meaning that we see across this conversation is very fluid. In this part of the conversation Richard is trying to remember the name for a type of crab, and is satisfied when Nancy produces the Mawng name for it, Mawuga, in line 167, he does not continue to search for the Dhuwal name for the crab as well. In the extract Mawng is shown in italics and Dhuwal with underline.

(7)

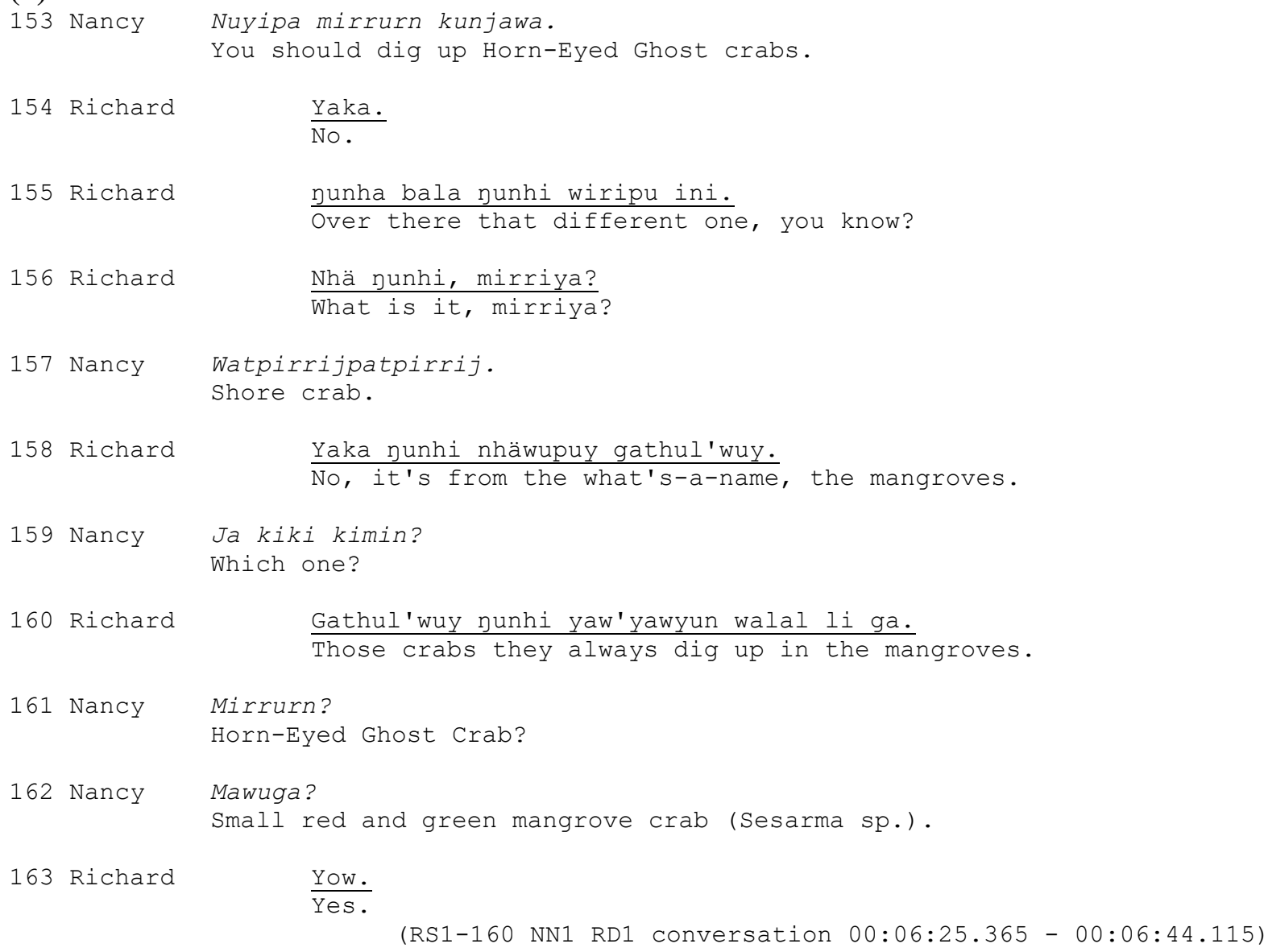


The conversation between Nancy and Janet Mardbinda shown earlier in extract (2) also flows very fluently. Nancy interviews Janet about a recent evacuation of Warruwi Community due to a cyclone. While Janet speaks Kunwinjku in this recording, Nancy again speaks in Mawng, although she has spoken Kunwinjku as well since childhood. A few years before the interview was done, when she was 17 , Janet also made a language portrait (Figure 5).

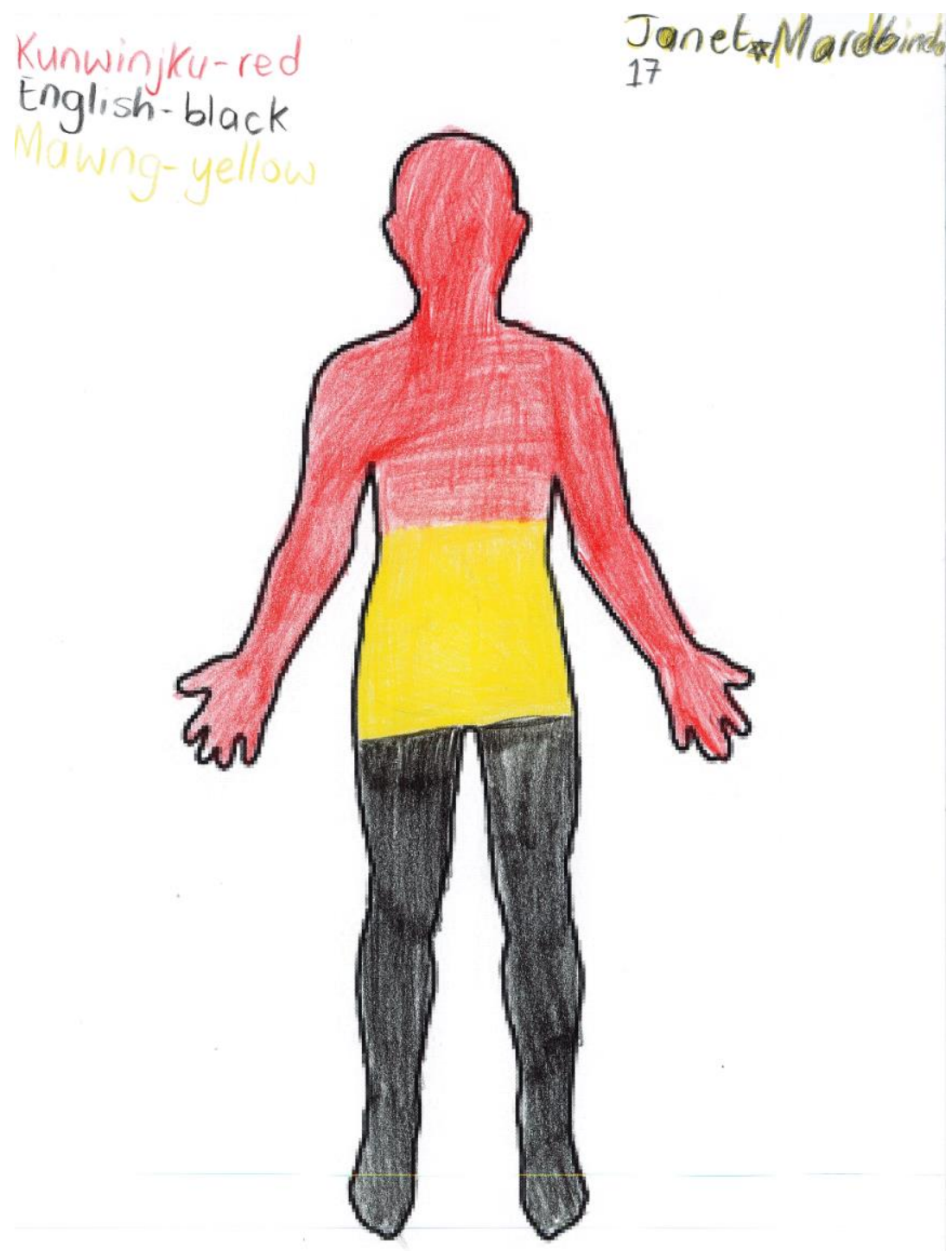

Figure 5 Janet Mardbinda's language portrait

Janet coloured the top part of her body in red to represent the Kunwinjku variety of Bininj Kunwok, her father's language which she speaks most of the time. She coloured the stomach area in yellow to represent Mawng and coloured the legs in black to represent English. The colour scheme she used draws on the colours of the Aboriginal flag shown in Figure 6 below. 


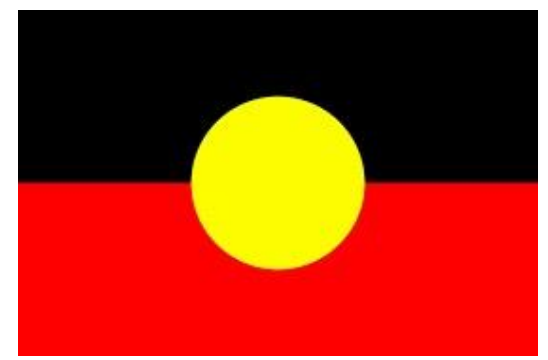

Figure 6 Australian Aboriginal flag

Janet, like Richard, understands Mawng very well, as she grew up at Warruwi and some of her main carers speak Mawng part of the time. However, she does not speak much Mawng. Her family has been very strict in insisting that she speak Kunwinjku all the time and avoid Mawng as they identify strongly as people from inland, who speak Kunwinjku. It is no concern to her family however if Janet listens to people speaking Mawng and understands it.

The way that people view their repertoires is closely connected to their identity. The right to speak a language is justified with reference to a kinship connection, ancestry or marriage for example. Although she has no eastern Arnhem Land ancestry, Nancy traces her right to use a Yolngu-matha variety to her marriage to her husband. Speaking this language has been very useful for her through her work with the church, which brings together Indigenous people from across Arnhem Land, many from eastern Arnhem Land. Identity can also be invoked when preventing people from speaking a language they might otherwise pick up. In this way, Janet has been brought up to speak Kunwinjku and not Mawng because of her Kunwinjku ancestry. Although identity is important to people's repertoires and language use it does not predict it. Agency, language-learning talents and opportunities for language learning also play an important role.

\section{The framing of receptive multilingualism at Warruwi}

The distinction between 'speaking' and 'hearing' a language is frequently expressed in discussions of language use in northern Australia which suggests that receptive multilingualism has always been widespread. For example, anthropologist Donald Thomson's 1928 notes from Cape York reveal that people described their linguistic repertoires in terms of speaking vs. hearing a language. The quote below is from his notes on the meaning of the Umpila word kuuku kankanhtha:

applied by these people to all the people from (\& including) the Stewart (Yintingka) Tribe whose languages are so distinct from their own that they cannot even "hear" or "listen" them. (This is their criterion, many languages well removed from their own they cannot talk but they can "hear").

Donald Thomson fieldnotes quoted by Rigsby (2005: 139)

Linguist Melanie Wilkinson, who has lived and worked in eastern Arnhem Land for four decades, recalls a language survey that was designed by local Indigenous people in eastern Arnhem Land. The distinction between 'speaking' and 'hearing' a language was something they incorporated into the survey design so it clearly reflects local views of the linguistic repertoire and language competency (Wilkinson, pers. comm. July 2017). While psycholinguists have found significant differences between the processing involved in 
production (i.e. speech) and comprehension, some argue that the two processes have much more in common than than is acknowledged (Pickering and Garrod, 2013). Looking more closely at people's language competencies at Warruwi, we find something more like a continuum than a strict division between 'speaking' and 'hearing'. Some people may 'hear' a language and speak it a little bit, while other 'hearers' strictly avoid speaking that language they only hear. The distinction between 'hearing' and 'speaking' a language is itself a kind of language ideology which provides a framework for describing people's linguistic proficiency across northern Australia where receptive multilingualism is widely practiced.

In the broader linguistics literature we find a view of receptive competence that treats it a kind of incomplete acquisition (Putnam and Sánchez, 2013). However, at Warruwi the ability to only 'hear' a language seems to be viewed as a separate kind of language proficiency rather than an inadequate version of a prototypical kind of proficiency. The Warruwi view does not imply that it is expected as part of normal language development that a person who can 'hear' a language will begin to 'speak' it later. At Warruwi there are people who have lived with speakers of Mawng, for example, their whole life like Janet Mardbinda or most of it as in Richard's case. They have not begun to speak Mawng and there is no expectation among others that they will do so. The fact that they have had ample opportunity to learn to speak Mawng is demonstrated by the fluency of their receptive multilingual conversations. They seem to avoid speaking Mawng largely for reasons of identity, in the case of Richard and Janet they both identify as being 'from somewhere else'.

\section{Conceptualising the multilingual speech community at Warruwi}

How do we understand the fact that Mawng is often said to be the common language of Warruwi Community (Singer and Harris, 2016), yet there are many people like Janet who have grown up at Warruwi but do not speak Mawng? Receptive multilingualism as an ordinary practice at Warruwi, co-constructs a context where those who have a claim to the Mawng language can use it in a fairly wide range of situations but it is also acceptable, perhaps even desirable for others who lack a valid claim to Mawng to avoid speaking it. At Warruwi, Mawng is recognised as the most significant language, the language that belongs to the place ${ }^{7}$. This makes the meaning of speaking Mawng at Warruwi different to elsewhere. Speaking Mawng is associated with a strong claim of belonging to Warruwi so the very act of speaking Mawng may be controversial for people who priortise claims to other places. The extent to which people orient to receptive multilingual practices as ordinary and everyday make Warruwi unusual even in western Arnhem Land (cf. Bilaniuk, 2005). The practice of receptive multilingualism in nearby communities seems to be less widespread, more restricted to interactions with speakers of smaller languages.

The intensive multilingualism at Warruwi is neither incidental nor marginal. Multilingualism has not arisen as an accident of people coming together in the post-contact era. Neither does multilingualism exist at the margins of imagined monolingual groups. Rather multilingualism at Warruwi reflects longstanding practices of speakers of smaller languages in western Arnhem Land. The political power of Mawng-affiliated people at Warruwi has enabled them to assert the centrality of the Mawng language at Warruwi. It is seen as the language of the community and also the language that belongs to the land of Warruwi ${ }^{8}$. This

\footnotetext{
${ }^{7}$ Some people argue that not just Mawng but 'Mawng, Kunwinjku and Kunbarlang' are the languages that belong to Warruwi (see Singer and Harris, 2016).

${ }^{8}$ See Singer (forthcoming, chapter 2 ) for a historical account.
} 
political achievement is probably the main reason why Mawng has been maintained across the generations, whereas other languages that had similar numbers of speakers a few generations ago such as Kunbarlang and Iwaidja are now spoken mainly by old people. What has been maintained at Warruwi is much more than just the Mawng language itself. What has also been maintained are the "mutually constituting ideologies and practices" (Nakassis 2016) that supported so many small languages in the past. At Warruwi it has been possible to project these onto a wider canvas- that of the contemporary remote Indigenous community of Warruwi. It is these mutually constituting practices and ideologies, equivalent to the 'shared norms' cited in accounts of the speech community, that make Warruwi Community a speech community.

Warruwi has always been much more than a place of residence, it has also always been a socio-political entity. The Indigenous origin story of Warruwi credits Kunwinjku speakers with finding the 'first missionary' wandering on the mainland, bringing him over to Warruwi and then negotiating good relations between the missionary and Mawng-affiliated families already living at Warruwi. This story cements the place of various groups and families at Warruwi (Singer, 2018). Warruwi Community has been treated as an entity by both Church and State since the establishment of the Goulburn Island Methodist Mission in 1916. However, since the disbanding of the ATSIC model of Indigenous self-governance in 2005 Warruwi has had little political representation-currently just two councillors on the local West Arnhem Shire council (Smith, 2008; Howitt, 2012). Regardless, people at Warruwi continue to work together for the benefit of the entire community in various ways.

Foundational work by Peter Sutton and Bruce Rigsby paid attention to how we conceptualise multilingual Indigenous Australian speech communities, drawing on their fieldwork in Cape York (Sutton, 1978, 1991, 1997; Sutton and Rigsby, 1979; Rigsby and Sutton, 1980). They make two suggestions in their work. The first suggestion that Rigsby and Sutton (1980) make is dispensing with the notion of the 'speech community' as somehow independent from groups and identities that emerge from ethnographic work. Although they do not mention it, the 'remote Indigenous community' has emerged as a significant reference point in remote-living Indigenous people's lives. People who have grown up together in a particular remote community or have other long-standing connections to the remote community tend to identify with it strongly. Warruwi Community itself is clearly a point of reference in young people's performances of their identities through use of labels such as SGI on group selfies on Facebook and in graffiti around the community (SGI is the abbreviation used in the aviation industry for South Goulburn Island-Warruwi in Mawng). Treating Warruwi Community as a speech community then, satisfies Rigsby and Sutton's (1980) suggestion, although their research in Cape York in the late 1970's and early 1980's, did not point to the importance of this kind of identity, which must have already been emerging.

Sutton (1978) and Rigsby and Sutton (1980)'s second suggestion is that we follow Silverstein $(1972 a, 1972 b, 1996)$ in using a separate notion of the 'language community' in addition to the 'speech community'. Silverstein's idea of separate speech and language communities is useful because it makes explicit the fact that the shared norms that define a speech community need not relate to language systems at all. Silverstein aims to create a bulwark against the continual tendency towards reductive conceptualisations of the speech community as users of a shared code, or people who orient to a single standard language (Labov, 1972). Although much has been written about this issue, this view continues to 
appear in the literature, because most linguists focus on a single language in their research and tend to imagine users of small languages as socially isolated (Trudgill, 2011). In an early exploration of the idea that there might be different 'kinds' of speech communities, Gumperz (1962) reiterates this isolationist view, in relation to hunter-gatherers, like the ancestors of Indigenous people at Warruwi:

1. Contact with outsiders is infrequent

2. Code variability only consists of a difference between casual and non-casual styles

3. There is little difference between casual and non-casual speech

4. There is minimal social stratification in language use

The idea of the 'dialectal-tribe' (see Sutton 1978, inter alia), a kind of ethnic group bounded by the use of a single language is still rife in the literature, although anthropologists of Indigenous Australia fought hard against this misconception in the late 1960's (Merlan, 1981; Singer, 2018). The underlying fantasy behind these conceptions, 'linguistic nationalism' is like a sinkhole that scholarly accounts tend to fall back on without even necessarily intending to. One reason is that simplification is often key to scholarly explication but simplification can easily blur into oversimplification. In addition, speakers of any languages while cognisant of the greater complexities do 'strategically essentialise' their own identities (Paradies, 2006). This strategy can be necessary in order to achieve some kind of political recognition (Povinelli, 2002) when talking with powerful groups who have no sense of the social and linguistic complexity of a specific locality (Lüpke, 2016). The continual search for new approaches to multilingualism, such as the recent 'superdiversity/translanguaging' push (Silverstein, 2015; Vaughan, forthcoming) is one such effort to push back against the oversimplifications that are projected by the monolingual mindset (Clyne, 2008). Exactly why scholars find it so hard to imagine and model multilingualism remains an open question.

Sutton constructed a convincing argument that "[linguistic] differences ... are internal to society, not markers of the edges of different societies" (Sutton, 1997) at Cape Keerweer, Cape York Peninsula in the 1970's. The nature of these Indigenous multilingual settings and how they differ from better-studied multilingual settings can be made clearer with reference to Silverstein's model of a separate 'language community' and speech community. However, the distinction between 'hearing' and 'speaking' a language that we find at Warruwi raises questions for how we would delimit these separate language communities? Would they include or exclude people who only 'hear' a language, or people who say Nganingka anyak 'I only speak it a little'? If we have a well-fleshed out model of a multilingual speech community, do we need Silverstein's 'language community' at all?

Speech communities do not exist of themselves. They are always emergent, contingent, contextual, invoked in a specific time and place for a specific purpose. Mutually constituting ideologies and practices circulate all the time, ready to be gathered together and indexed as 'shared norms' for the creative imagining a specific speech community. This happens not only in the imagination of the researcher but is also something that participants in a study and other stakeholders do. A researcher may well define a speech community as a means of making their study bounded and manageable. However study participants and other stakeholders will also invoke speech communities within their discussions with the researcher and through their language use. These might support their particular authenticity projects or political pursuits such as land claims. When I interviewed people 
about language use at Warruwi Community, they did not move to subtly correct my assumptions by shifting the point of reference to western Arnhem Land or 'Mawng speakers' in order to invoke some other conceptualisation of the speech community. The open-endedness of our discussions and way that people often referred to other remote communities such as nearby Gunbalanya, Minjilang and Maningrida in our discussions, suggests that remote Indigenous communities are treated as meaningful points of reference in talking about language use ${ }^{9}$.

Warruwi is clearly a 'complex communicative economy' which weaves together a multiplicity of languages and social groupings through widely upheld shared norms of language use. The claim made here that Warruwi Community is a valid speech community for the purposes of the analysis of language use, is a claim that Warruwi has a particular set of shared norms, that are not exactly the same as elsewhere. It is a claim that Warruwi Community is not taken as the study site simply because it is practical, and there is a sea to cross to get to other nearby communities. Rather, that language users at Warruwi have a specific shared history and connected identities so that even if they identify as 'not being from Warruwi' they still engage with ideologies and practices that are specific to Warruwi.

Language ideologies such as the idea that people own their father's father's language were probably found in most Indigenous communities (Sutton, 1997; Merlan, 1981). The practice of receptive multilingualism has also been reported from many Indigenous communities. However receptive multilingualism seems to be tied to the maintenance of small languages such as Mawng in a quite specific way (cf. Green 2003a, on Gurrgoni, an even smaller local language). Although most language practices and ideologies found at Warruwi are also found across a much wider area, the way they fit together as a set of mutually constitutive set of practices and ideologies at Warruwi is unique and bound up with the community's specific socio-political history and the social and linguistic groups which make a claim to it.

\section{Acknowledgements}

This work draws on extensive discussions with members of Warruwi Community, and the fieldwork was supported by Warruwi Community and Warruwi School. Thanks especially to Janet Mardbinda, Rachel Meiyinbara, Nancy Ngalmindjalmag and Richard Dhangalangal for their participation in the research leading to this article. Discussions with Susy Macqueen while doing fieldwork helped to deepen the discussion and analysis of linguistic repertoires in this paper. I would like to thank audiences at the University of Melbourne, SOAS, University of Oslo and the Australian Languages Workshop for their responses to some of the ideas in this paper. Thanks very much to Jill Vaughan and Sari Pietikäinen for their comments on the article. Research was funded by the Australian Research Council (DE140100232 and FL130100111) and travel support from SOAS (University of London), the University of Melbourne and the Fritz Thyssen Stiftung.

\section{References}

Bilaniuk, L., 2005. Contested tongues: Language politics and cultural correction in Ukraine. Cornell University Press, Ithaca.

Bloomfield, L., 1933. Language. Henry Holt, New York.

\footnotetext{
${ }^{9}$ A remote community often stands in metonymically for a particular social or linguistic group or the land around it and its owners.
} 
Bristowe, A., Oostendorp M., Anthonissen C., 2014. Language and youth identity in a multilingual setting: A multimodal repertoire approach. Southern African Linguistics \& Applied Language Studies 32(2), 229-245.

Brown, R., 2016. Following footsteps: The kun-borrk/manyardi song tradition and its role in western Arnhem Land society. PhD thesis, Sydney University, Sydney.

Busch, B., 2006. Language biographies for multilingual learning: linguistic and educational considerations. In Busch, B., Jardine, A., Tjoutuku, A. (Eds.), Language biographies for multilingual learning, (Occasional Papers No. 24). Project for the Study of Alternative Education in South Africa (PRAESA), Cape Town, pp. 5-17.

Busch, B., 2010. School language profiles: valorizing linguistic resources in heteroglossic situations in South Africa. Language and Education 24, 283:294.

Busch, B., 2012. The linguistic repertoire revisited. Applied linguistics 33, 503-523.

Capell, A., 1942. Languages of Arnhem Land, North Australia. Oceania 12(4), 364-392.

Carr, S.E., Lempert M., 2016. Pragmatics of scale. In Carr, S.E., Lempert M. (Eds.), Scale: discourse and dimensions of social life. University of California Press, California.

Clark, M., Sally K.M., 2013. Macassan History and Heritage: Journeys, Encounters and Influences. ANU ePress, Canberra.

Clyne, M., 2008. The monolingual mindset as an impediment to the development of plurilingual potential in Australia. Sociolinguistic Studies 2(3), 347-365.

Coffey, S., 2015. Reframing teachers' language knowledge through metaphor analysis of language portraits. The Modern Language Journal 99(3), 500-514.

Dressler, R., 2015. Exploring linguistic identity in young multilingual learners. TESL Canada Journal 32(1), 42.

Elwell, V.M.R., 1977. Multilingualism and lingua francas among Australian Aborigines: a case study of Maningrida. Honours thesis. Australian National University, Canberra.

Elwell, V.M.R., 1982. Some social factors affecting multilingualism among Aboriginal Australians: a case study of Maningrida. International Journal of the Sociology of Language 36, 83-103.

Faudree, P., 2015. Singing for the dead, on and off line: Diversity, migration, and scale in Mexican Muertos music. Language \& Communication (Special issue: The Social Life of Diversity Talk). 44, 31-43.

Faudree, P., Schulthies, B., 2015. Introduction: "diversity talk" and its others. Language \& Communication (Special issue: The Social Life of Diversity Talk). 44, 1-6.

Giles, H., Ogay. T., 2007. Communication accommodation theory. In Samter, W., Whaley B.B., (Eds.), Explaining communication: Contemporary theories and exemplars. Lawrence Erlbaum associates, Mahwah, New Jersey, pp. 293-310.

Giles, H., Powesland P.F., 1975. Speech style and social evaluation. Academic Press, London and New York.

Green, J., Bauer, A., Gaby, A., Ellis, E.M., in press. Pointing to the body: kin signs in Australian Indigenous sign language. Gesture.

Green, R., 2003a. Gurr-goni, a minority language in a multilingual community: surviving into the 21st century. In Blythe, J., Brown, R.M. (Eds.), Maintaining the links: language, identity and the land. Foundation for Endangered Languages, Bath, pp. 127-134.

Green, R., 2003b. Proto Maningrida within Proto Arnhem: evidence from verbal inflectional suffixes. In Evans, N., (Ed.), The non-Pama-Nyungan languages of Northern Australia: comparative studies of the continent's most linguistically complex region. Pacific Linguistics, Canberra, pp. 369-421. 
Gumperz, J., 1962. Types of linguistic communities. Anthropological linguistics. (1962), 2840.

Gumperz, J., 1968. The speech community. International Encyclopaedia of the Social Sciences, Macmillan, New York, pp. 381-386.

Howitt, R., 2012. Sustainable indigenous futures in remote Indigenous areas: relationships, processes and failed state approaches. GeoJournal 77(6), 817-828.

Kroskrity, P.V., 1993. Language, history and identity: ethnolinguistic studies of the Arizona Tewa. The University of Arizona Press, Tuscon.

Labov, W., 1972. Sociolinguistic Patterns. University of Pennsylvania Press, Philadelphia.

Lüpke, F., 2016. Pure fiction - the interplay of indexical and essentialist language ideologies and heterogeneous practices: A view from Agnack. In Seyfeddinipur, M. (Ed.), African language documentation: new data, methods and approaches. Language Documentation and Conservation, Special Publication No. 10, pp. 8-39.

Lupyan, G., Dale, R., 2010. Language Structure Is Partly Determined by Social Structure. PLoS ONE 5(1), e8559. doi:10.1371/journal.pone.0008559.

Merlan, F., 1981. Land, language and social identity in Aboriginal Australia. Mankind 13, 133-148.

Nakassis, C.V., 2016. Linguistic Anthropology in 2015: Not the Study of Language. American Anthropologist. 118, 330-345

O'Keeffe, I., 2016. Multilingual manyardi/kun-borrk: Manifestations of multilingualism in the classical song traditions of western Arnhem Land. PhD Thesis, University of Melbourne, Melbourne.

Paradies, Y.C., 2006. Beyond black and white: Essentialism, hybridity and indigeneity. Journal of Sociology 42(4), 355-367.

Pearson, N., 1997. The Concept of Native Title at Common Law. In Yunupingu, G., (Ed.), Our Land Is Our Life: Landrights - Past,Present And Future. University of Queensland Press, St Lucia, pp. 150-162.

Pickering, M.J., Garrod. S., 2013. An integrated theory of language production and comprehension. Behavioral and Brain Sciences 36(4), 329-347.

Pietikäinen, S., Jaffe, A., Kelly-Holmes, H., Coupland, N., 2016. Sociolinguistics from the Periphery: Small Languages in New Circumstances. Cambridge University Press, Cambridge.

Pietikäinen, S., Pitkänen-Huhta, A., 2013. Multimodal Literacy Practices in the Indigenous Sámi Classroom: Children Navigating in a Complex Multilingual Setting. Journal of Language, Identity \& Education 12(4), 230-247.

Povinelli, E.A., 2002. The cunning of recognition: Indigenous alterities and the making of Australian multiculturalism. Duke University Press, Durham.

Putnam, M.T., Sánchez, L., 2013. What's so incomplete about incomplete acquisition?: A prolegomenon to modeling heritage language grammars. Linguistic Approaches to Bilingualism 3(4), 478-508.

Rampton, B., 2010. Speech Community. In Jaspers, J., Östman, J-O., Verschueren, J (Eds.), Society and Language Use. John Benjamins, Amsterdam, pp. 274-303

Rigsby, B. J., 2005. The languages of eastern Cape York Peninsula and linguistic anthropology. In Peterson, N., Rigsby, B., (Eds.), Donald Thomson, the man and scholar. The Academy of the Social Sciences in Australia, Canberra, pp. 129-142.

Rigsby, B. J., Sutton, P., 1980. Speech communities in aboriginal Australia. Anthropological Forum 5(1), 8-23. 
Rumsey, A., 1989. Language groups in Australian Aboriginal land claims. Anthropological Forum 6, 69-79.

Scott, J.C., 1999. Seeing Like a State. Yale University Press, New Haven.

Shnukal, A., 1991. Torres Strait Creole. In Romaine. S. (Ed.), Language in Australia. Cambridge University Press, Cambridge, pp. 180-194.

Sicoli, M.A., 2011. Agency and ideology in language shift and language maintenance. In Granadillo, T., and Orcutt-Gachiri, H., (Eds.), Ethnographic contributions to the study of endangered languages. University of Arizona, Tucson, pp. 161-176.

Silverstein, M., 1972a. Chinook Jargon: Language contact and the problem of multi-level generative systems, I. Language (1972), 378-406.

Silverstein, M., 1972b. Chinook Jargon: Language contact and the problem of multi-level generative systems, II. Language 48(3). 596-625.

Silverstein, M., 1996. Classifiers, verb classifiers and verbal categories. Berkeley Linguistic Society $12,497-514$.

Silverstein, M., 2015. How Language Communities Intersect: Is "superdiversity" an incremental or transformative condition? Language \& Communication 44, 7-18.

Singer, R., forthcoming. Language at Warruwi: multilingualism in a remote Indigenous community, manuscript.

Singer, R., 2018. The wrong t-shirt: configurations of language and identity at Warruwi Community. The Australian Journal of Anthropology. 10.1111/taja.12264

Singer, R., Harris, S., 2016. What practices and ideologies support small-scale multilingualism? a case study of unexpected language survival in an Australian Indigenous community. International Journal of the Sociology of Language 241, 163208.

Smith, D., 2008. Cultures of governance and the governance of culture: transforming and containing Indigenous institutions in West Arnhem Land. In Hunt, J., Smith, D., Garling, S., Sanders, W, (Eds.) Contested Governance: culture, power and institutions in Indigenous Australia (CAEPR Research Monograph No. 29). ANU Press, Canberra, pp. 75-112.

Sutton, P., 1978. Wik Aboriginal society, territory and language at Cape Keerweer, Cape York Peninsula. PhD Thesis, University of Queensland, St. Lucia.

Sutton, P., 1991. Language in Aboriginal Australia: Social dialects in a geographic idiom. In Romaine. S., (Ed.), Language in Australia. Cambridge University Press, Cambridge, pp. 49-66.

Sutton, P., 1997. Materialism, Sacred Myth and Pluralism: Competing theories of the Origin of Australian Languages. In Merlan, F., Morton, J., Rumsey, A., (eds.), Scholar and Sceptic: Australian Aboriginal Studies in Honour of L.R. Hiatt. Aboriginal Studies Press, Canberra, pp. 211-242.

Sutton, P., Rigsby, B., 1979. Linguistic communities and social networks in Cape York Peninsula. In Wurm, S.A., (Ed.), Australian Lingusitic Studies (vol. C-54) Pacific Linguistics, Canberra, pp. 713-732.

Trudgill, P., 2011. Sociolinguistic typology: the social determinants of linguistic complexity. Oxford University Press, Oxford.

Vaughan, J., forthcoming. Translanguaging and the construction of difference in north central Arnhem Land in Translanguaging in Everyday Practice (Multilingual Education Series). Springer, New York. 
Verschik, A., 2012. Practising receptive multilingualism: Estonian-Finnish communication in Tallinn. International Journal of Bilingualism 16(3), 265-286. 